\title{
ANALISIS BRIKET KELAPA SEBAGAI BAHAN BAKAR ALTERNATIF
}

\author{
Yafet Bontong \\ Teknik Mesin, Fakultas Teknik, Universitas Kristen Indonesia Toraja
}

\begin{abstract}
ABSTRAK
Analisis pemanfaatan briket bagian-bagian kelapa sebagai bahan bakar alternatif. Penelitian ini bertujuan melakukan pengujian proksimasi nilai kalor. Menentukan efisiensi thermal briket arang kelapa dengan komposisi bahan perekat dan penguat.

Metode penelitian yang digunakan adalah metode eksperimen dengan memanfaatkan briket bagian-bagian kelapa sebagai bahan bakar pada kompor untuk mendidihkan air.

Hasil uji nilai kalor rata-rata yang didapat ialah B1 sebesar 5341,66 cal/gram, B2 sebesar $4047 \mathrm{cal} /$ gram, danB3 sebesar 6010,66 cal/gram. Hasil uji pembakaran pada tiga jenis briket yang berbeda menunjukkan bahwa B3 yang paling unggul dalam hal mendidihkan air sebanyak 6 (enam) kali dengan efisiensi pembakaran yang dihasilkan sebesar $58,92 \%$.
\end{abstract}

Kata kunci :Briket Arang Batang, Sabut, dan Tempurung kelapa,nilai kalor dan efisiensi pembakaran.

\subsection{Latar Belakang}

BABI

\section{PENDAHULUAN}

Beberapa tahun terakhir ini energi merupakan persoalan yang krusial di dunia.Peningkatan permintaan energi yang disebabkan oleh pertumbuhan populasi penduduk dan menipisnya sumber cadangan minyak dunia serta permasalahan emisi dari bahan bakar fosil memberikan tekanan kepada setiap negara untuk segera memproduksi dan menggunakan energi terbarukan.Selain itu, peningkatan harga minyak dunia sudah mencapai100 U\$ per barel juga menjadi alasan yang serius yang menimpah banyak negara di dunia terutama Indonesia.

Menurut data ESDM (2006) cadangan minyak Indonesia hanya tersisa sekitar 9 milliar barel. Apabila terus dikonsumsi tanpa ditemukanya cadangan minyak baru, diperkirakan cadangan minyak yang dimiliki oleh Indonesia akan habis dalam dua dekade mendatang.Untuk mengurangi ketergantungan terhadap bahan bakar minyak, pemerintah telah menerbitkan peraturan Presiden Republik Indonesia nomor 5 tahun2006 tentang kebijakan energi nasional untuk mengembangkan sumber energi alternatif sebagai pengganti bahan bakar minyak. Kebijakan tersebut menekankan pada sumber daya yang dapat diperbaharui sebagai energi alternatif pengganti bahan bakar minyak.

Biomassa atau bahan-bahan organik ini dapat diolah dan dijadikan sebagai bahan bakar alternatif contohnya dengan pembuatan briket.Sumber energi jenis ini banyak diperoleh dari hasil kehutanan,peternakan, danperkebunan. Salah satu contoh pemanfaatan energi biomassa yang berasal dari produkaktifitas perkebunan kelapa ialah batang, sabut, dan tempurung yang merupakan bagian dari kelapa.

Oleh karena itu mengoptimalkan bahan bakar alternatif serta memanfaatkan bagian-bagian dari kelapa sebagai bahan bakar pengganti minyak 
tanah dan meningkatkan efektifitas dan efisiensi dari bahan bakar alternatif tersebut.

\subsection{Rumusan Masalah}

Berdasarkan uraian pada latar belakang, maka rumusan masalah yang hendak diteliti adalah sebagai berikut :

1. Bagaimana menentukan nilai kalor dari bagian-bagian kelapa?

2. Bagaimana menentukanefisiensi pembakaran dari bagian-bagian kelapa?

\subsection{Tujuan Penelitian}

Adapun tujuan yang hendak dicapai dalam penelitian ini sekaligus menjadi solusi dari rumusan masalah di atas adalah sebagai berikut :

1. Untuk menentukannilai kalor dari bagian-bagian kelapa.

2. Untuk menentukan efisiensi pembakaran dari bagian-bagian kelapa.

\subsection{Batasan Masalah}

Penelitian ini mengunakan bahan briket berupa bagian-bagian dari kelapa,makapenulis membatasi masalah seperti di bawah ini:

1. Bahan baku yang digunakan adalah tiga bagian-bagian kelapa yaitu batang, sabut, dan tempurung kelapa.

2. Bahan perekat dan penguat yang digunakan pada pembuatan briket adalah tepung tapioka dan tanah liat, masing-masing 75 gram.

3. Pembuatan briket arangbatang, sabut, dan tempurung kelapa berbentuk sarang tawon dengandiameter $63 \mathrm{~mm}$ dan tinggi $40 \mathrm{~mm}$.

4. Proses pembakaran briket menggunakan kompor briket dengan metode pendidihan air.

\subsection{Manfaat Penelitian}

Adapun manfaat dari hasil penelitian ini diharapkan :

1. Bagi akademis, dapat memberikan kontribusi ilmiah tentang karakteristik briket arang kelapa dan potensi energi yang terkandung didalamnya.

2. Bagi Industri, dapat dijadikan sebagai salah satu sumber energi alternatif.

3. Bagi Peneliti, dapat dijadikan sebagai acuan dan perbandingan untuk penelitian selanjutnya yang berhubungan dengan objek ini.

4. Bagi Masyarakat, dapat mengetahuai tentang penggunaan bagian-bagian dari pohon kelapa yang dianggap sebagai sesuatu yang tidak berguna.

\subsection{Hasil Penelitian Sebelumnya}

MenurutSiti Jamilatun, (2008) ; Hasil penelitian menunjukkan bahwa tempurung kelapa memiliki lama menyala terpanjang yaitu 116 menit dengan nilai kalor sebesar $5779.11 \mathrm{cal} /$ gram.

Riska Sahputri, Syafruddin Syafruddin, Selvie Diana (2010) ; Hasil penelitian menunjukkan bahwa nilai kalor briket hasil perbandingan antara batang jagung dan tempurung kelapa 25\% : 75\% perekat 10\% yaitu sebesar 5132,17 cal/gram.

Sallolo Suluh, (2014) ; Mendapatkan nilai kalor briket tempurung kelapa $4949 \mathrm{cal} / \mathrm{gram}$ dan memperoleh efisiensi thermal sebesar $24.96 \%$. 
Dari beberapa penelitian sebelumnya dihasilkan nilai kalor yang berbeda-beda, kemungkinan karena proses pembuatan yang berbeda dan komposisi bahan briket yang digunakan.

\subsection{Biomassa Sebagai Sumber Energi}

Biomassa adalah suatu limbah benda padat yang bisa dimanfaatkan lagi sebagai sumber bahan bakar.Biomassa meliputi limbah kayu, limbah pertanian, limbah perkebunan,limbah hutan, komponen organik dari industri, dan rumah tangga. Energi biomassa dapat menjadi sumber energi alternatif pengganti bahan bakar fosil (minyak bumi) karena beberapa sifatnya yang menguntungkan yaitu sumber energi ini dapat dimanfaatkan secara lestari karena sifatnya yang dapat diperbaharui (renewable resources), sumber energi ini relatif tidak mengandung unsur sulfur sehingga tidak menyebabkan polusi udara dan juga dapat meningkatkan efisiensi pemanfaatan sumber daya hutan dan pertanian.

Teknologi konversi thermal biomassa meliputi pembakaran langsung, gasifikasi, dan pirolisis atau karbonisasi.Masing-masing metode memiliki karakteristik yang berbeda dilihat dari komposisi udara dan produk yang dihasilkan.Potensi energi terbarukan yang besar dan belum banyak dimanfaatkan adalah energi dari biomassa. Potensi energi biomassa sebesar 50.000 MW hanya $320 \mathrm{MW}$ yang sudah dimanfaatkan atau hanya $0,64 \%$ dari seluruh potensi yang ada. Potensi biomassa di Indonesia bersumber dari produk limbahkelapa sawit, penggilingan padi, kayu, pabrik gula, kakao, dan limbah industri pertanian lainnya.

\section{BAB III \\ METODOLOGI PENELITIAN}

Metode penelitian yang digunakan adalah metode eksperimen dengan membuat briket arang dari tiga bagian-bagiankelapa dalam bentuk silinder berlubang (sarang tawon), kemudian melakukan pengujian nilai kalor (LHV) dan pengujian pembakaran pada kompor briket. Adapun komposisi bagian-bagian kelapa dengan kombinasi bahan perekat dan penguat dapat dilihat pada tabet 3.1 dibawah ini.

Tabel 3.1 Komposisi briket kelapa

$\begin{array}{lcccccc}\text { No } & \text { Sampel } & \begin{array}{r}\text { Batang } \\ \text { kelapa } \\ \text { (gram) }\end{array} & \begin{array}{c}\text { Sabut } \\ \text { kelapa } \\ \text { (gram) }\end{array} & \begin{array}{c}\text { Tempurung } \\ \text { kelapa } \\ \text { (gram) }\end{array} & \begin{array}{c}\text { Tanah liat } \\ \text { (gram) }\end{array} & \begin{array}{c}\text { Tepung } \\ \text { tapioka } \\ \text { (gram) }\end{array} \\ \text { 1. } & \text { B1 } & 850 & - & - & 75 & 75 \\ \text { 2. } & \text { B2 } & - & 850 & - & 75 & 75 \\ \text { 3. } & \text { B3 } & - & - & 850 & 75 & 75\end{array}$




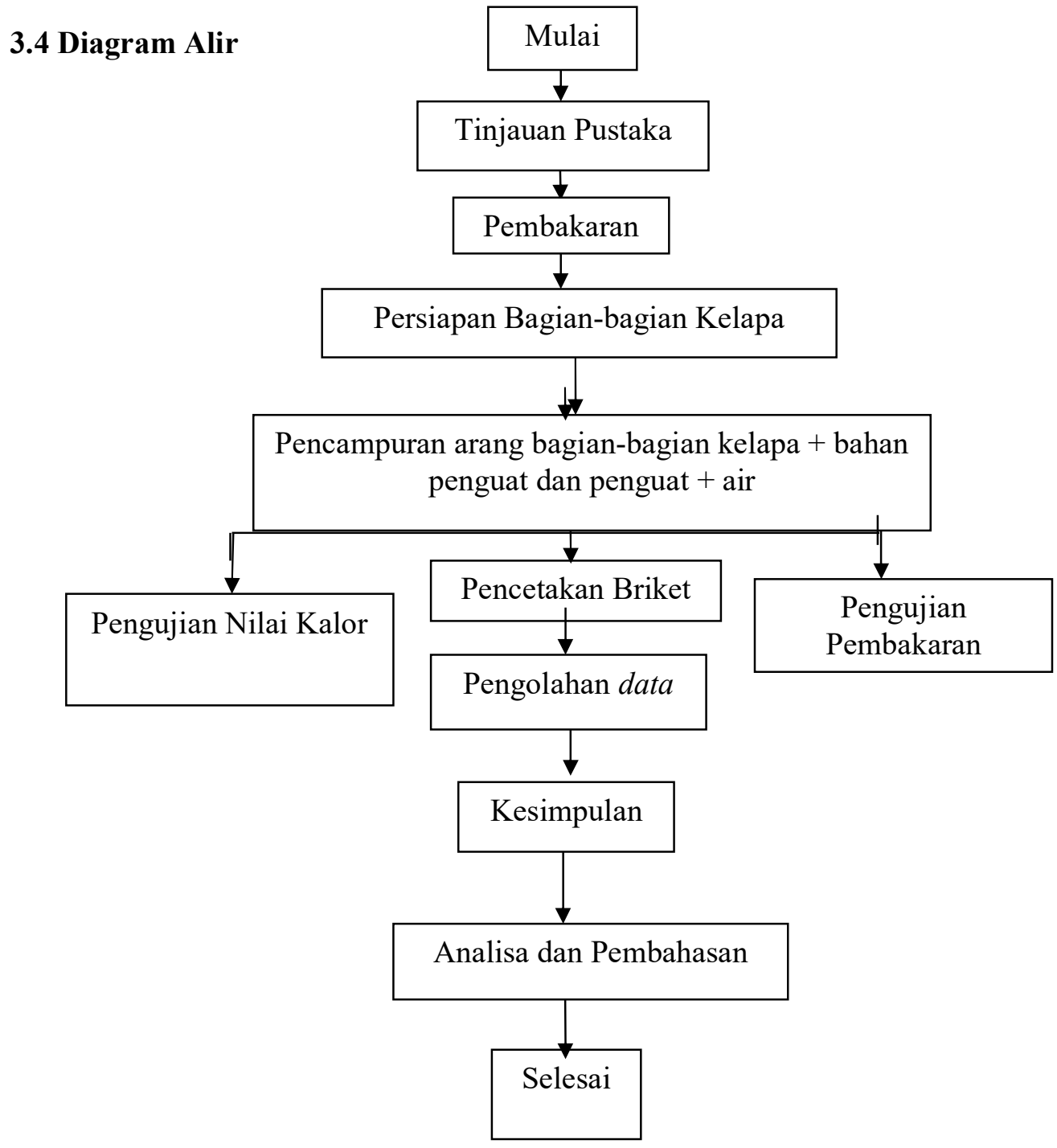

Gambar 3.4 Diagram Alir Penelitian

\section{BAB IV \\ HASIL DAN PEMBAHASAN}

\subsection{Hasil Penelitian}

Hasil penelitian ini meliputi pembuatan briket, pengujian proksimasi, nilai kalor dan uji pembakaran (kinerja) pada tiga jenis briket arangbagian-bagian kelapa.

\subsubsection{Pembuatan briket arang kelapa dalam bentuk sarang tawon}


Briket dari bagian-bagian kelapa yang dibuat dalam bentuk sarang tawon, telah berhasil dibuat dengan menggunakan alat cetak seperti Gambar 4.1 dibawah ini. Sebelumnya telah dilakukan usaha perbaikan kualitas dengan cara memperbaiki proses pengarangan (mengurangi kadar abu) dan proses pengeringan (mengurangi kadar air) serta penggunaan partikel arang sebesar 40 mesh.

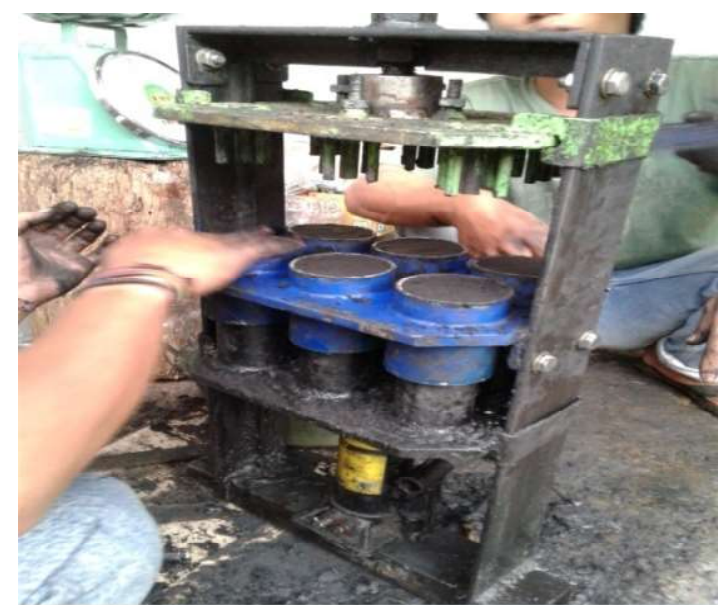

Gambar 4.1. Alat Cetak Briket

Sumber : Foto Scan (2017)

Briket dibuat dan dicetak dalam bentuk silinder berlubang / sarang tawon seperti Gambar dibawah ini :

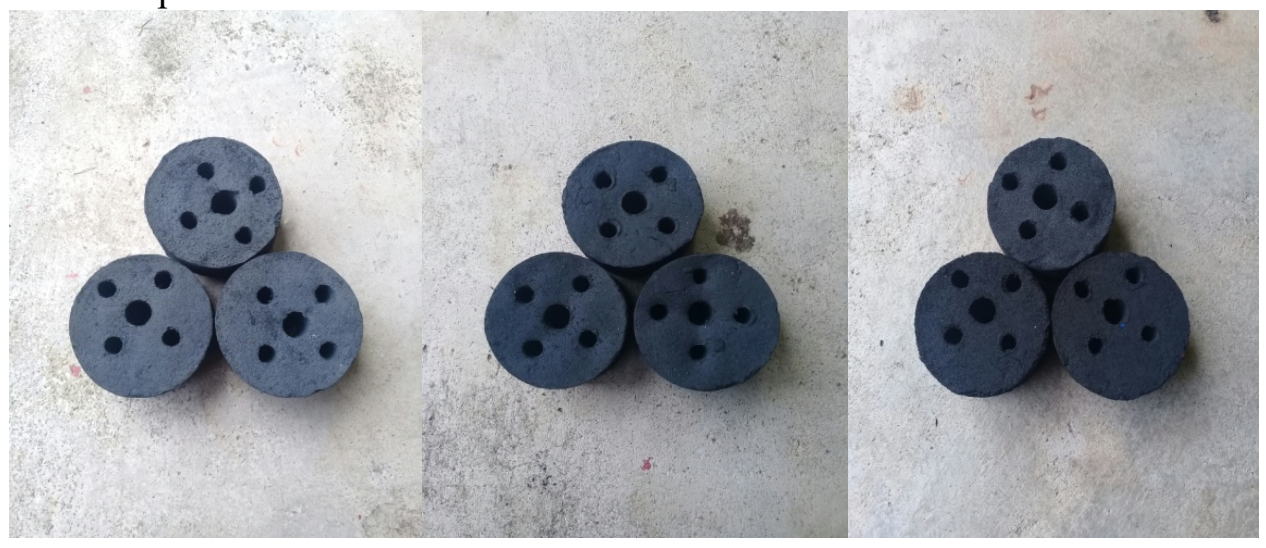

Gambar 4.2. Briket yang dihasilkan

Sumber : Foto Scan (2017)

Briket 1

$$
\text { Briket } 2
$$

Briket 3

\subsubsection{Spesifikasi ukuran briket :}

1) Briket bentuk silinder (sarang tawon)

Briket yang dihasilkan mempunyai dimensi rata-rata diameter $(\mathrm{d})=63 \mathrm{~mm}$, tinggi masing-masing briket yang dihasilkan B1 $=45 \mathrm{~mm}, \mathrm{~B} 2=45 \mathrm{~mm}, \mathrm{~B} 3$ $=45 \mathrm{~mm}$ diameter lubang tengah briket $(\mathrm{d})=15 \mathrm{~mm}$ dan diameter sekeliling $(\mathrm{d} 1)=8 \mathrm{~mm}$ (empat buah).

2) Massa dan volume briket 
Massa briketnya adalah 117 gram

\subsubsection{Pengujian Nilai Kalor}

Pengujian nilai kalor dilakukan di laboratorium kimia makanan ternak Fakultas Peternakan Universitas Hasanuddin dengan hasil dapat dilihat pada Tabel 4.1.

Tabel 4.1 Hasil nilai kalor

\begin{tabular}{|c|c|c|}
\hline No & Kode Sampel & $\begin{array}{c}\text { Nilai Rata-rata } \\
\text { (cal/gram) }\end{array}$ \\
\hline 1. & B1 & 5476 \\
\hline 2. & B1 & 5221 \\
\hline 3. & B1 & 5328 \\
\hline & Rata-rata & 5341,66 \\
\hline 1. & B2 & 4060 \\
\hline 2. & B2 & 4045 \\
\hline 3. & B2 & 4036 \\
\hline & Rata-rata & 4047 \\
\hline 1. & B3 & 6012 \\
\hline 2. & B3 & 6021 \\
\hline 3. & B3 & 5999 \\
\hline & Rata-rata & 6010,66 \\
\hline
\end{tabular}

\subsubsection{Pengujian pembakaran dan efisiensi pembakaran.}

Data pengujian pembakaran briket pada kompor briket dengan metode pendidihan air dengan menggunakan tiga jenis briket dapat dilihat pada lampiran 2, 3, daan 4 .

\section{A. Pembakaran briket}

1. Briket $\mathrm{B} 1$ menghasilkan data sebagai berikut :
a. Temperatur maksimum $\left(\mathrm{T}_{\max }\right) \quad: 674^{\circ} \mathrm{C}$
b. Lama Pembakaran (t)
: 140 menit
c. Mendidihkan air sebanyak
: 4 kali ( masing-masing $0,8 \mathrm{~kg}$ )
d. Temperatur akhir air
: $61^{\circ} \mathrm{C}$

2. Briket $\mathrm{B} 2$ menghasilkan data sebagai berikut :
a. Temperatur maksimum $\left(\mathrm{T}_{\max }\right): 476^{\circ} \mathrm{C}$
b. Lama Pembakaran (t)
: 155 menit
c. Mendidihkan air sebanyak
: 3 kali (masing-masing $0,8 \mathrm{~kg}$ )
d. Temperatur akhir air$$
\text { : } 66^{\circ} \mathrm{C}
$$

3. Briket $\mathrm{B} 3$ menghasilkan data sebagai berikut:
a. Temperatur maksimum $\left(\mathrm{T}_{\max }\right) \quad: 717^{\circ} \mathrm{C}$
b. Lama Pembakaran (t)
: 190 menit
c. Mendidihkan air sebanyak
d. Temperatur akhir air
: 6 kali (masing-masing $0,8 \mathrm{~kg}$ )
: $68^{\circ} \mathrm{C}$

Data hasil pembakaran briket dan pendidihan air untuk 3 jenis briket yang berbeda, dapat juga dilihat padagambar 4.5 (B1), gambar 4.6 (B2), dan gambar 4.7 (B3).Pada masing-masing grafik tersebut digambarkan temperatur api briket 
dan temperatur air terhadap waktu pembakaran yang digunakan dalam kemampuan mendidihkan air satu kali atau lebih.

\section{B. Efisiensi Thermal}

Efisiensi merupakan besarnya energi panas yang digunakan selama proses perubahan bentuk energi yang bermanfaat dibagi besarnya energi panas yang dilepaskan oleh bahan bakar selama proses pembakaran.

1. Efisiensi thermal B1

Perhitungan diambil efisiensi thermal untuk briket B1 dalam mendidihkan air sebanyak 4 kali dan temperatur api di dapatkan sebesar $674^{\circ} \mathrm{C}$ dengan waktu pembakaran briket selama 140 menit ( 2 jam $20 \mathrm{mnt}$ ). Dan menghabiskan briket yang terbakar sebanyak 0,34 kg. Selanjutnya dapat dilihat data-datanya sebagai berikut :
a. $\mathrm{m}_{\mathrm{a}}=$ massa air yang dipanaskan $(\mathrm{kg})=0,8 \mathrm{~kg}$
b. $\mathrm{m}_{\mathrm{p}}=$ massa panci $(\mathrm{kg})=0,25 \mathrm{~kg}$
c. $\mathrm{m}_{\mathrm{bb}}=$ massa briket yang telah terpakai $(\mathrm{kg})=0,34 \mathrm{~kg}$
d. $\mathrm{m}_{\mathrm{u}}=$ massa uap air $(\mathrm{kg})=0,28 \mathrm{~kg}$
e. $\mathrm{H}_{L}=$ Kalor laten dari uap $(\mathrm{kJ} / \mathrm{kg})=2256,487 \mathrm{~kJ} / \mathrm{kg}$
f. $\mathrm{Cp}_{\text {air }}=$ kalor spesifik air $\left(\mathrm{kJ} / \mathrm{kg}{ }^{0} \mathrm{C}=4,1769 \mathrm{~kJ} / \mathrm{kg}{ }^{0} \mathrm{C}\right.$
g. $\mathrm{Cp}_{\mathrm{al}}=$ kalor spesifik aluminium $\left(\mathrm{kJ} / \mathrm{kg}{ }^{0} \mathrm{C}\right)=0,9 \mathrm{~kJ} / \mathrm{kg}{ }^{0} \mathrm{C}$
h. $L H V=$ nilai kalor bawah briket $(\mathrm{kJ} / \mathrm{kg})$$$
=((5341,66 x 4,1866 \mathrm{~kJ} / \mathrm{kg})-3240 \mathrm{~kJ} / \mathrm{kg})=19123,421 \mathrm{~kJ} / \mathrm{kg}
$$
i. $\mathrm{T}_{\mathrm{b}}=$ temperatur air awal $\left({ }^{\circ} \mathrm{C}\right)=27^{\circ} \mathrm{C}$
j. $\mathrm{T}_{\mathrm{a}}=$ temperatur didih air dalam panci $\left({ }^{\circ} \mathrm{C}\right)=100{ }^{\circ} \mathrm{C}$
k. $\mathrm{T}_{\mathrm{c}} \quad=$ temperatur api $\left({ }^{\circ} \mathrm{C}\right)=674^{\circ} \mathrm{C}$

Dengan menggunakan persamaan, maka diperoleh efisiensi termal sebagai berikut :

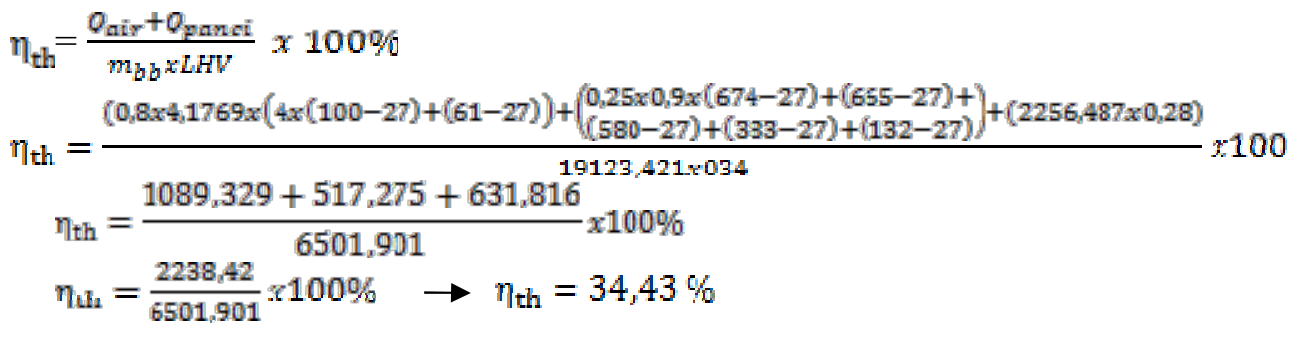

2. Efieiensi thermal B2

Perhitungan diambil efisiensi thermal untuk briket B2 dalam mendidihkan air sebanyak 3 kali dan temperatur api di dapatkan sebesar $476^{\circ} \mathrm{C}$ dengan waktu pembakaran briket selama 155 menit ( 2 jam 35 menit ). Dan menghabiskan briket yang terbakar sebanyak $0,34 \mathrm{~kg}$. Selanjutnya dapat dilihat data-datanya sebagai berikut :
a. $\mathrm{m}_{\mathrm{a}}=$ massa air yang dipanaskan $(\mathrm{kg})=0,8 \mathrm{~kg}$
b. $\mathrm{m}_{\mathrm{p}}=$ massa panci $(\mathrm{kg})=0,25 \mathrm{~kg}$
c. $\mathrm{m}_{\mathrm{bb}}=$ massa briket yang telah terpakai $(\mathrm{kg})=0,34 \mathrm{~kg}$
d. $\mathrm{m}_{\mathrm{u}}=$ massa uap air $(\mathrm{kg})=0,15 \mathrm{~kg}$
e. $\mathrm{H}_{L}=$ Kalor laten dari uap $(\mathrm{kJ} / \mathrm{kg})=2256,487 \mathrm{~kJ} / \mathrm{kg}$ 


$$
\begin{array}{ll}
\text { f. } \mathrm{Cp}_{\text {air }} & =\text { kalor spesifik air }\left(\mathrm{kJ} / \mathrm{kg}{ }^{0} \mathrm{C}=4,1769 \mathrm{~kJ} / \mathrm{kg}{ }^{0} \mathrm{C}\right. \\
\text { g. } \mathrm{Cp}_{\mathrm{al}} & =\text { kalor spesifik aluminium }\left(\mathrm{kJ} / \mathrm{kg}{ }^{0} \mathrm{C}\right)=0,9 \mathrm{~kJ} / \mathrm{kg}{ }^{0} \mathrm{C} \\
\text { h. } L H V & =\text { nilai kalor bawah briket }(\mathrm{kJ} / \mathrm{kg}) \\
& =((4047 \mathrm{x} 4,1866 \mathrm{~kJ} / \mathrm{kg})-3240 \mathrm{~kJ} / \mathrm{kg})=13703,170 \mathrm{~kJ} / \mathrm{kg} \\
\text { i. } \mathrm{T}_{\mathrm{b}}=\text { temperatur air awal }\left({ }^{\circ} \mathrm{C}\right)=27{ }^{\circ} \mathrm{C} \\
\text { j. } \mathrm{T}_{\mathrm{a}}=\text { temperatur didih air dalam panci }\left({ }^{\circ} \mathrm{C}\right)=100{ }^{\circ} \mathrm{C} \\
\text { k. } \mathrm{T}_{\mathrm{c}}=\text { temperatur api }\left({ }^{\circ} \mathrm{C}\right)=476{ }^{\circ} \mathrm{C}
\end{array}
$$

Dengan menggunakan persamaan, maka diperoleh efisiensi termal sebagai berikut :

$$
\begin{gathered}
\eta_{\text {th }}=\frac{Q_{\text {air }}+Q_{\text {panci }}}{m_{b b^{2 L H V}}} \times 100 \% \\
\eta_{\text {th }}=\frac{\left(0,8 \times 4,1769 \times(3 \times(100-27)+(66-27))+\left(\begin{array}{c}
0,25 \times 0,9 \times(476-27)+(344-27)+ \\
(211-27)+(100-27)
\end{array}\right)+(2256,487 \times 0,15)\right.}{13703,170 \times 0,34} \times 100 \\
\eta_{\text {th }}=\frac{862,107+230,175+338,473}{4659,077} \times 100 \% \\
\eta_{\text {th }}=\frac{1430,755}{4659,077} \times 100 \% \rightarrow \eta_{\text {th }}=30,70 \%
\end{gathered}
$$

3. Efisiensi thermal B3

Perhitungan diambil efisiensi thermal untuk briket B3 dalam mendidihkan air sebanyak 6 kali dan temperatur api di dapatkan sebesar $717^{\circ} \mathrm{C}$ dengan waktu pembakaran briket selama 190 menit ( 3 jam $10 \mathrm{mnt}$ ). Dan menghabiskan briket yang terbakar sebanyak $0,30 \mathrm{~kg}$. Selanjutnya dapat dilihat data-datanya sebagai berikut :
a. $\mathrm{m}_{\mathrm{a}}=$ massa air yang dipanaskan $(\mathrm{kg})=0,8 \mathrm{~kg}$
b. $\mathrm{m}_{\mathrm{p}}=$ massa panci $(\mathrm{kg})=0,25 \mathrm{~kg}$
c. $\mathrm{m}_{\mathrm{bb}}=$ massa briket yang telah terpakai $(\mathrm{kg})=0,30 \mathrm{~kg}$
d. $\mathrm{m}_{\mathrm{u}}=$ massa uap air $(\mathrm{kg})=0,72 \mathrm{~kg}$
e. $\mathrm{H}_{L}=$ Kalor laten dari uap $(\mathrm{kJ} / \mathrm{kg})=2256,487 \mathrm{~kJ} / \mathrm{kg}$
f. $\mathrm{Cp}_{\text {air }}=$ kalor spesifik air $\left(\mathrm{kJ} / \mathrm{kg}{ }^{0} \mathrm{C}=4,1769 \mathrm{~kJ} / \mathrm{kg}{ }^{0} \mathrm{C}\right.$
g. $\mathrm{Cp}_{\mathrm{al}}=$ kalor spesifik aluminium $\left(\mathrm{kJ} / \mathrm{kg}{ }^{0} \mathrm{C}\right)=0,9 \mathrm{~kJ} / \mathrm{kg}{ }^{0} \mathrm{C}$
h. $L H V=$ nilai kalor bawah briket $(\mathrm{kJ} / \mathrm{kg})$

$$
=((6010,66 \times 4,1866 \mathrm{~kJ} / \mathrm{kg})-3240 \mathrm{~kJ} / \mathrm{kg})=21924,257 \mathrm{~kJ} / \mathrm{kg}
$$
i. $\mathrm{T}_{\mathrm{b}}=$ temperatur air awal $\left({ }^{\circ} \mathrm{C}\right)=27^{\circ} \mathrm{C}$
j. $\mathrm{T}_{\mathrm{a}}=$ temperatur didih air dalam panci $\left({ }^{\circ} \mathrm{C}\right)=100{ }^{\circ} \mathrm{C}$
k. $\mathrm{T}_{\mathrm{c}}=$ temperatur api $\left({ }^{\circ} \mathrm{C}\right)=717^{\circ} \mathrm{C}$

Dengan menggunakan persamaan, maka diperoleh efisiensi termal sebagai berikut :

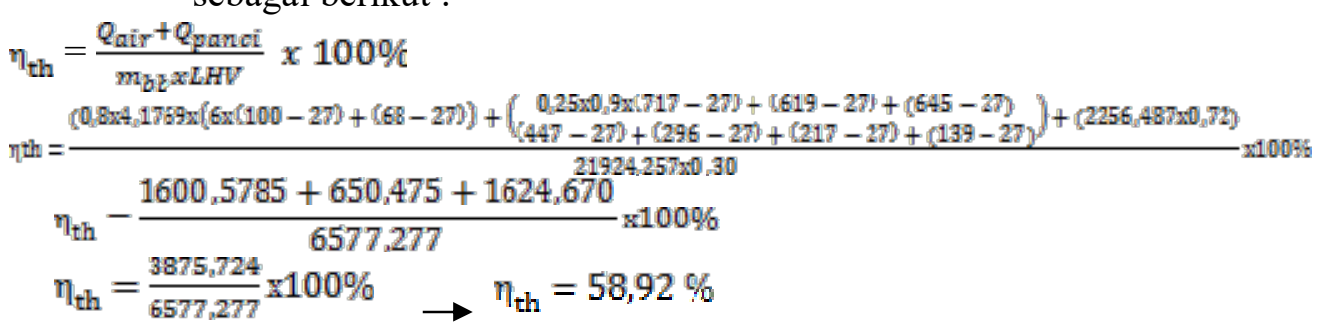

Tabel 4.2 Hasil maksimum efisiensi yang dihasilkan

$\begin{array}{cccc}\text { Kode sampel } & \text { B1 } & \text { B2 } & \text { B3 } \\ \text { Ma (kg) } & 0,8 & 0,8 & 0,8\end{array}$




$\begin{array}{lccc}\mathrm{Mp}(\mathrm{kg}) & 0,25 & 0,25 & 0,25 \\ \mathrm{Mu}(\mathrm{kg}) & 0,28 & 0,15 & 0,72 \\ \mathrm{Cp} \text { air }\left(\mathrm{kj} / \mathrm{kg}^{\circ} \mathrm{C}\right) & 4,1769 & 4,1769 & 4,1769 \\ \mathrm{Cp} \mathrm{al}\left(\mathrm{kj} / \mathrm{kg}^{\circ} \mathrm{C}\right) & 0,9 & 0,9 & 0,9 \\ \mathrm{Ta}\left({ }^{\circ} \mathrm{C}\right) & 100 & 100 & 100 \\ \mathrm{~Tb}\left({ }^{\circ} \mathrm{C}\right) & 27 & 27 & 27 \\ \mathrm{TC}\left({ }^{\circ} \mathrm{C}\right) & 674 & 476 & 717 \\ \text { Briket terpakai }(\mathrm{kg}) & 0,34 & 0,34 & 0,30 \\ \text { LHV }(\mathrm{kj} / \mathrm{kg}) & 19123,421 & 13703,170 & 21924,257 \\ \eta_{\text {th }}(\%) & 34,43 & 30,70 & 58,92\end{array}$

\subsection{Pembahasan}

Berdasarkan hasil penelitian yang terdapat pada sub bab hasil penelitian, maka pembahasan pada bagian ini meliput :

1. Hasil pembuatan briket arang bagian-bagian kelapa.

2. Hasil pengujian dan nilai kalor.

3. Hasil pengujian pembakaran pada kompor briket.

\subsubsection{Hasil pembuatan briket bagian-bagian kelapa berdasarkan variasi bahan penguat.}

Briket bagaian-bagian kelapa telah berhasil dibuat menjadi briket dalam bentuk sarang tawon dengan mesin pencetak. Jumlah briket yang dihasilkan dalam penelitian ini adalah masing-masing bagian kelapa sebanyak 10 buah. Sebelumya telah dilakukan berbagai usaha untuk meningkatkan kualitas briket itu sendiri antara lain : memaksimalkan penggeringan bahan baku sebelum dan sesudah penggarangan, kemudian memisahkan arang dan abu dengan menggunakan jenis saringan yang berukuran 40 mesh sehingga abu dapat terbuang. Selain itu juga ditambahkan tepung tapioka untuk menambah kerapatan dan kuat tekan briket.

\subsection{Kesimpulan}

\section{BAB V KESIMPULAN}

Dari penelitian yang telah dilakukan mulai dari bulan mei sampai juli untuk tiga jenis bagian-bagian kelapa mulai dari pembuatan hingga pengujian briket, maka dapat disimpulkan bahwa :

1. Nilai kalor yang paling tinggi adalah B3 (tempurung kelapa) dengan nilai kalor sebesar 6010,66 cal/gram, disusul B1(batang kelapa) sebesar 5341.66 cal/gram dan paling rendah adalah B2 (sabut kelapa) sebesar $4047 \mathrm{cal} / \mathrm{gram}$.

2. Perhitungan efisiensi pembakaran menunjukkan bahwa B3 mempunyai efisiensi tertinggi yaitu 58,92 \%, disusul dengan B1 sebesar 34,43\%dan yang paling rendah adalah B2 sebesar 30,70\% 


\section{DAFTAR PUSTAKA}

Andi Haryati, Norsamsi, Putri Suci Ranny Sholiha, Novy Pralisa Putri.,2014. Studi Pemanfaatan Limbah Kelapa Sawit, Konversi Volume 3 No.2. http://ppjp.unlam.ac.id Diakses 28 april 2017

Endang Kusman.,2013.Tungku Hemat Kayu bakar untuk Masyarakat Pedesaan.http://www.endangkusman.wordpress.com/tungku_hemat_kayu_untuk_ma syarakat_pedesaan. Diaskes 09 desember 2016.

http://www.petanihebat.com/2013/09/klasifikasi-dan-morfologi-tanamankelapa.html

Idzni Qistina.,2016. Kajian Kualitas Briket dari Sekam Padi dan Tempurung Kelapa. Jurnal Kimia Valensi Vol.2, No 2, http://journal.uinjkt.ac.id Diakses 18 april 2017

Mahadir Sirman.,2013. Peningkatan Kualitas Briket Campuran Limbah Ketam Kayu Merbabu, Sekam Padi dan Tongkol Jagung Pada Berbagai Komposisi. Laporan Penelitian Fakultas Teknik Universitas Hasanuddin

Maryono, Sudding, \& Rahmawati,,2013. Pembuatan dan Analisis Mutu Briket Arang Tempurung Kelapa Ditinjau dari Kadar Kanji. Jurnal 1411-6502 Vol.14, No 1,http://unm.ac.id Diakses 27 april 2017

Rahmawati, S. 2013. Pemanfaatan Kulit Rambutan (Nephelium sp.) untuk Bahan Pembuatan Briket Arang Sebagai Bahan Bakar Alternatif. Prosiding Simposium Nasional Inovasi dan Pembelajaran Sains 2013. Diakses 18 april 2017

Riska Sahputri, Syafruddin syafruddin, Selvie Diana.,2010. Pembuatan Briket Arang Jagung dan Tempurung Kelapa. Beranda $>$ vol 8, No 2, http://e-jurnal.pul.ac.id Diakses 28 april 2017

Sallolo Suluh, Effendy Arif, \& Yusuf Siahaya.,2014 Peningkatan Kinerja Berbagai Kompor Dengan Bahan Bakar Briket Limbah Biomassa. Laporan Penelitian Teknik Mesin. Universitas Hasanuddin

Tri Kusuma Wardani.,2014 Campuran Ampas Limbah Tebu (Bagasse) dan Arang Tempurung Kelapa Dengan Perekat Tetes Tebu. Jurnal Teknik Mesin Vo.13, No 01, http://googleweblight.com Diakses 27 april 2017 
Siti Jamilatun.,2008. Sifat-sifat Penyalaan dan Pembakaran Briket Biomassa, Briket

Batubara dan Arang Kayu. Jurnal Rekayasa Proses, Vol. 2, No 2. Diakses 27 april 2017

\section{LAMPIRAN}

Lampiran 1: Data hasil pengujian proksimasi dan nilai kalor

Tabel 1.1 Hasil analisis nilai kalor B1

\begin{tabular}{|c|c|c|c|c|c|c|}
\hline \multirow[b]{2}{*}{ No } & \multirow{2}{*}{$\begin{array}{c}\text { Kode } \\
\text { Sampel }\end{array}$} & \multicolumn{4}{|c|}{ Komposisi \% } & \multirow{2}{*}{$\begin{array}{l}\text { Nilai Kalor } \\
\text { (cal/gram) }\end{array}$} \\
\hline & & Air & $\mathrm{Abu}$ & Volatil Metter & $\begin{array}{c}\text { Fixed } \\
\text { Carbon } \\
\end{array}$ & \\
\hline 1. & B1 & 10,71 & 24,92 & 17,93 & 46,44 & 5476 \\
\hline 2. & $\mathrm{~B} 1$ & 10,55 & 24,56 & 17,34 & 47,55 & 5221 \\
\hline 3. & B1 & 10,29 & 24,78 & 17,67 & 47,26 & 5328 \\
\hline \multicolumn{2}{|c|}{ Rata-rata } & 10,51 & 24,75 & 17,64 & 47,08 & 5341,66 \\
\hline
\end{tabular}

Tabel1.2 Hasil analisis nilai kalor B2

\begin{tabular}{|c|c|c|c|c|c|c|}
\hline \multirow{2}{*}{ No } & \multirow{2}{*}{$\begin{array}{c}\text { Kode } \\
\text { Sampel }\end{array}$} & \multicolumn{4}{|c|}{ Komposisi \% } & \multirow{2}{*}{$\begin{array}{l}\text { Nilai Kalo } \\
\text { (cal/gram) }\end{array}$} \\
\hline & & Air & $\mathrm{Abu}$ & Volatil Metter & Fixed Carbon & \\
\hline 1. & B2 & 18,38 & 27,33 & 17,41 & 36,88 & 4060 \\
\hline 2. & $\mathrm{~B} 2$ & 18,44 & 27,48 & 17,66 & 36,42 & 4045 \\
\hline 3. & B2 & 18,95 & 27,77 & 17,93 & 35,35 & 4036 \\
\hline \multicolumn{2}{|c|}{ Rata-rata } & 18,59 & 27,52 & 17,66 & 36,21 & 4047 \\
\hline
\end{tabular}

Tabel1.3Hasil analisis nilai kalor B3

\begin{tabular}{|c|c|c|c|c|c|c|}
\hline \multirow{2}{*}{ No } & \multirow{2}{*}{$\begin{array}{c}\text { Kode } \\
\text { Sampel }\end{array}$} & Air & Abu & $\begin{array}{c}\text { Volatil } \\
\text { Metter }\end{array}$ & Fixed Carbon & $\begin{array}{c}\text { Nilai Kalor } \\
\text { (cal/gram) }\end{array}$ \\
\cline { 3 - 6 } & B3 & 8,99 & 11,22 & 26,04 & 53,75 & 6012 \\
\hline 2. & B3 & 8,68 & 11,48 & 26,87 & 52,61 & 6021 \\
\hline 3. & B3 & 8,36 & 11,49 & 26,98 & 53,17 & 5999 \\
\hline \multicolumn{2}{|c|}{ Rata-rata } & 8,67 & 11,39 & 26,63 & 53,17 & 6010,66 \\
\hline
\end{tabular}

